Abstract-Abundances of Gulf menhaden (Brevoortia patronus) in the northern Gulf of Mexico (GOM) are heavily influenced by physical and biological processes that affect refuge and food availability. This study identified specific decadal and interannual responses in the recruitment of Gulf menhaden to local meteorological and hydrological regimes imposed by the coupling of Atlantic Multidecadal Oscillation (AMO) and North Atlantic Oscillation (NAO) phases and by El Niño Southern Oscillation (ENSO) events. Numbers of age- 0 menhaden in fishery-independent surveys and numbers and proportions of Gulf menhaden ages 1-6 in commercial purse-seine landings in the northern GOM were used to investigate those responses. High postlarval abundance of Gulf menhaden (3.6/beam plankton haul) in the central region was related to the decadal wet regime associated with AMO cold and NAO positive phases. Elevated numbers of menhaden species (38.3/seine haul) in the western region were related to interannual wet regimes associated with ENSO warm and neutral events. High commercial landings of Gulf menhaden (10 million fish/vessel ton week) were related to the decadal average hydrological regime associated with AMO cold and NAO negative phases. Climate regimes may favor growth and survival by structuring offshore and inshore nursery habitats or by synchronizing release of larvae when offshore and inshore nursery conditions are favorable.

Manuscript submitted: 13 September 2013. Manuscript accepted: 16 July 2015.

Fish. Bull. 113:391-406 (2015).

Online publication date: 14 August 2015. doi: 10.7755/FB.113.4.3

The views and opinions expressed or implied in this article are those of the author (or authors) and do not necessarily reflect the position of the National Marine Fisheries Service, NOAA.

\title{
Climate-related meteorological and hydrological regimes and their influence on recruitment of Gulf menhaden (Brevoortia patronus) in the northern Gulf of Mexico
}

\author{
Guillermo Sanchez-Rubio (contact author) \\ Harriet Perry \\ Email address for contact author: guillermo.sanchez@usm.edu \\ Gulf Coast Research Laboratory \\ Center for Fisheries Research and Development \\ University of Southern Mississippi \\ 703 East Beach Drive \\ Ocean Springs, Mississippi 39564
}

Gulf menhaden (Brevoortia patronus) spawn in offshore marine waters and juvenile development occurs in nearshore nursery areas. Spawning occurs in the late fall and winter, peaking between December and February (Gunter, 1945; Guillory and Roussel, 1981; Shaw et al., 1985; Christmas et al. ${ }^{1}$ ). On the basis of the distribution of eggs, Fore (1970) noted that spawning occurred mainly over the continental shelf in the northcentral Gulf of Mexico (GOM) and that the greatest concentrations were found in waters between 8 and $70 \mathrm{~m}$ off Texas and Louisiana and near the Mississippi River Delta. Christmas and Waller (1973) and Sogard et al. (1987) also found high densities of larvae near the Mississippi River. Late-stage larvae recruit to estuaries during the winter and spring, and there they transform into juveniles and remain for several months before moving back to open Gulf waters (Suttkus, 1956; Christmas and

\footnotetext{
${ }^{1}$ Christmas, J. Y., D. J. Etzold, L. B. Simpson, and S. Meyers (eds.). 1988. The menhaden fishery of the Gulf of Mexico United States: a regional management plan. Gulf States Mar. Fish. Comm. 18, 134 p. [Available at website.]
}

Waller, 1973) in the summer and fall (Suttkus, 1956). After metamorphosis of larvae into juveniles, Gulf menhaden change their feeding habits from a carnivorous diet to an omnivorous filter-feeding diet.

The capacity of estuaries to support growth and development was considered by Reintjes (1970) to be critical to survival of young Gulf menhaden. A host of studies have examined the effects of meteorological and hydrological variables on recruitment success (numbers of juvenile fish moving into the estuary) and most have focused on annual fluctuations. More recent data indicate that global climate factors associated with decadal and multidecadal oscillations in the Pacific and Atlantic influence population abundances of estuarine species in addition to the annual and interannual factors noted in earlier studies.

The Pacific Decadal Oscillation (PDO), Atlantic Multidecadal Oscillation (AMO), North Atlantic Oscillation (NAO), and El Niño Southern Oscillation (ENSO) are associated with river flows across the continental United States (Tootle et al., 2005; Tootle and Piechota, 2006). The combination of PDO, AMO, and NAO and 
the coupling of AMO and NAO phases were found to be important drivers of long-term flows in the Mississippi River and Atchafalaya River and in the Pearl River and Pascagoula River, respectively (Sanchez-Rubio et al., 2011a). The effect of ENSO on river flow is more evident in smaller river basins closely associated with the Gulf Coast environment (Sanchez-Rubio et al., 2011a).

Mississippi River flow is tightly linked to physical and biological processes associated with the development and survival of early stages of Gulf menhaden on the continental shelf and in estuaries of the northcentral GOM (Grimes and Finucane, 1991; Govoni and Grimes, 1992). From fall through early spring, biological productivity is enhanced by offshore transport and upwelling induced by northerly (north-south wind direction) and easterly (east-west wind direction) winds. Vector winds (Hitchcock et al., 1997) spread and project the Mississippi-Atchafalaya River plume over shelf waters as far as $100 \mathrm{~km}$ (Riley, 1937), resulting in a buoyant, nutrient-rich, freshwater mass with a welldefined frontal zone that veers westward in spring (Govoni et al., 1989; Govoni and Grimes, 1992; Hitchcock et al., 1997). Gulf menhaden larvae aggregate in the river plume front on the continental shelf where the Coriolis force, wind speed, and wind direction shape the trajectory and properties of the plume that transports larvae (Govoni et al., 1989; Govoni and Grimes, 1992; Hitchcock et al., 1997) as far west as Texas (Dinnel and Wiseman, 1986).

Mississippi-Atchafalaya river flow is positively related to the seaward projection and areal coverage of the plume (Wright and Coleman, 1971; Walker and Rouse $^{2}$ ) and to the influx of nutrient-rich river water (Bratkovich et al., 1994). Seaward projection and areal expansion through high river discharge may prolong shoreward transport of larvae and increase vulnerability to predation (Govoni, 1997). Nutrient enhancement (Riley, 1937; Lohrenz et al., 1990; Dagg and Whitledge, 1991) during high river discharge increases food availability and growth, thereby decreasing predation and increasing survival of Gulf menhaden larvae (Govoni, 1997). The river plume eventually enters the coastal current (Cochrane and Kelly, 1986; Wiseman and Kelly, 1994), exchanging water (Dinnel and Wiseman, 1986; Wiseman and Garvine, 1995) and transporting Gulf menhaden larvae (Govoni, 1993) between the current and the coastal boundary zone. Larvae, once they are within the coastal boundary zone, enter estuaries with the vernal rise in sea level (Shaw et al., 1985).

Juvenile development takes place in the estuary. During this period, interannual, strong northerly winds (coming from the north) promote coastal upwelling, increase nearshore productivity, and produce extremely low tide levels along the Gulf Coast with a resultant

\footnotetext{
2 Walker, N. D., and L. J. Rouse Jr. 1993. Satellite assessment of Mississippi River discharge plume variability. OCS Study MMS 93-0044. U.S. Dep. Interior, Minerals Manage. Serv., Gulf of Mexico OCS Region, New Orleans, 50 p. [Available at website.]
}

die off of marsh vegetation (Kirby, 1972; Day et al., 1973). This vegetation, accumulated during the winter, is later washed out by spring flood tides, stimulating spring plankton production (Guillory et al., 1983). The availability of food is further increased by high river flow that introduces new organic material to inshore waters and re-suspends existing detritus (Deegan and Thompson, 1985; Madden et al., 1988), fostering faster growth and increased survival of young Gulf menhaden (Deegan, 1990).

For early life history stages, food availability is a critical aspect of habitat suitability (Christmas et al., 1982; Deegan, 1986), and climate plays a crucial role in the structuring of habitats. Despite the economic and ecological importance of Gulf menhaden, studies of climate-related hydrological regimes on population abundances have been limited primarily to the study of annual and interannual factors thought to influence survival of larvae and juveniles. In this study, the effects of decadal AMO and NAO phases as well as interannual ENSO events on northern GOM hydrological conditions were examined and related to abundances of menhaden documented in fishery-independent and fishery-dependent data.

Two other species of menhaden have overlapping distribution ranges with the Gulf menhaden (Tolan and Newstead, 2004). In the western GOM, juveniles of the finescale menhaden (Brevoortia gunteri) may cooccur with Gulf menhaden, and juvenile populations in that area are therefore referred to in this manuscript as menhaden species (Tolan and Newstead, 2004; Anderson and Karel, 2014). The range of yellowfin menhaden (B. smithi) overlaps that of Gulf menhaden in the eastern portion of the northern GOM; however, estuarine collections of Brevoortia in Alabama bays have yielded only Gulf menhaden (Boschung et al., 2004). Menhaden in fishery-independent studies in the central GOM (Louisiana, Mississippi, and Alabama) are almost exclusively Gulf menhaden (SEDAR ${ }^{3}$ ). A host of studies have examined stock structure in the northern GOM, and all reveal that the fishery is composed of Gulf menhaden and other menhaden species, the latter of which represent less than $1 \%$ of the harvest (VanderKooy and Smith $^{4}$ ).

We examined fishery-independent data and fisherydependent data to identify the responses of menhaden populations to local meteorological and hydrological conditions imposed by the coupling of AMO and NAO phases and by ENSO events. Fishery-independent data included data 1) on Gulf menhaden from surveys conducted with beam plankton trawls [BPLs] in the central region, 2) on Gulf menhaden from

\footnotetext{
${ }^{3}$ SEDAR (Southeast Data, Assessment, and Review). 2013. SEDAR 32A-Gulf of Mexico menhaden assessment report, 422 p. SEDAR, North Charleston, NC. [Available at website.]

${ }^{4}$ VanderKooy, S. J, and J. W. Smith (eds.). 2015. The menhaden fishery of the Gulf of Mexico, United States: a regional management plan, 181 p. Gulf States Mar. Fish. Comm. 240 [Available at website.]
} 


\section{Table 1}

Periods and sources of climatological, meteorological, hydrological, and biological data used in analysis of the effect of climate-related factors on the recruitment of menhaden in the northern Gulf of Mexico. N:P ratio=nitrogen to phosphorus ratio; $\mathrm{BPL}=$ beam plankton trawl; $\mathrm{hPa}=$ hectopascal; $\mathrm{h}=$ hour.

\begin{tabular}{lcccc}
\hline Variables & Units & Years & Months & Sources \\
\hline Atlantic Multidecadal Oscillation & ${ }^{\circ} \mathrm{C}$ & $1962-2010$ & Jul-Jun & ESRL $^{1}$ \\
North Atlantic Oscillation & $\mathrm{hPa}$ & $1962-2010$ & Apr-Mar & NCAR $^{2}$ \\
El Niño Southern Oscillation & ${ }^{\circ} \mathrm{C}$ & $1962-2010$ & May-Feb & ESRL $^{3}$ \\
Coastal air temperature & ${ }^{\circ} \mathrm{C}$ & $1962-2010$ & Nov-Mar & NCDC $^{4}$ \\
Precipitation & $\mathrm{Mm}$ & $1962-2010$ & Sep-Aug & NCDC $^{4}$ \\
River flows & $\mathrm{m}^{3} / \mathrm{s}$ & $1962-2010$ & Sep-Aug & USGS $^{5}$ \\
Palmer Drought Severity Index & & $1962-2010$ & Sep-Aug & NCDC $^{4}$ \\
Sea level & $\mathrm{Mm}$ & $1962-2010$ & Nov-May & GLOSS $^{6}$ \\
Offshore wind momentum & {$\left[\mathrm{N} / \mathrm{m}^{2}\right] \mathrm{h}$} & $1973-2010$ & Oct-Mar & NDBC $^{7}$ \\
Sea-surface temperature & ${ }^{\circ} \mathrm{C}$ & $1973-2010$ & Oct-Mar & NDBC $^{7}$ \\
N:P ratio of Mississippi River influx & & $1974-2010$ & Sep-Aug & USGS $^{8}$ \\
Postlarval abundance index from BPL surveys & & $1981-2008$ & Nov-May & ADCNR $^{9}$ MSDMR $^{10}$ \\
Early juvenile abundance index from seine surveys & & $1985-2008$ & Jan-Aug & ADCNR $^{9}$ LDWF \\
& & & & MSDMR $^{10} ;$ TPWC $^{12}$ \\
Numbers and proportions per vessel ton week by age & & $1964-2010$ & Mid-Apr-Oct & Smith and Vaughan $^{13}$
\end{tabular}
in the purse-seine fishery

${ }^{1}$ ESRL (Earth Systems Research Laboratory). AMO unsmoothed from the Kaplan SST V2. [Available at website, accessed May 2012.]

${ }^{2}$ NCAR (National Center for Atmospheric Research). Hurrell NAO Index (PC-based). [Available at website, accessed May 2012.]

${ }^{3}$ ESRL (Earth Systems Research Laboratory). ENSO: 3.4 SST Region. [Available at website, accessed May 2012.]

${ }^{4}$ NCDC (National Climatic Data Center). Air temperature, precipitation, and Palmer Drought Severity Index. [Available at website, accessed May 2012.]

${ }^{5}$ USGS (U.S. Geological Survey). River flows along the Gulf Coast. [Available at website, accessed May 2012.]

${ }^{6}$ GLOSS (Global Sea Level Observing System). Sea level for Pensacola and Galveston. [Available at website, accessed May 2012.]

${ }^{7}$ NDBC (National Data Buoy Center). Wind direction, wind speed, and sea-surface temperature from 42001 and 42002 buoy stations. [Available at website, accessed May 2012.]

${ }^{8}$ USGS (U.S. Geological Survey). Mississippi River predicted loads of monthly nutrients. [Available at website, accessed May 2012.]

${ }^{9}$ ADCNR (Alabama Department of Conservation and Natural Resources). 2011. Unpubl. data. [Beam plankton net and bag seine data from fishery monitoring program.] ADCNR, Montgomery, AL 36130.

${ }^{10}$ MSDMR (Mississippi Department of Marine Resources). 2011. Unpubl. data. [Beam plankton net and bag seine data from fishery monitoring program.] MSDMR, Biloxi, MS 39530.

${ }^{11}$ LDWF (Louisiana Department of Wildlife and Fisheries). 2011. Unpubl. data. [Bag seine data from fishery monitoring program.] LDWF, Baton Rouge, LA 70898.

${ }^{12}$ TPWC (Texas Parks and Wildlife Commission). 2011. Unpubl. data. [Bag seine data from fishery monitoring program.] TPWC, Austin, TX 78744.

${ }^{13}$ Smith, J. W., and D. S. Vaughan. 2011. Harvest, effort, and catch-at-age for Gulf menhaden. Southeast Data, Assessment, and Review SEDAR 27-DW05, 28 p. [Available at website.]

seine hauls in the central region, and 3) menhaden species from seine hauls in the western region. Fishery-dependent data included numbers and proportions of Gulf menhaden by age captured in the reduction purse-seine fishery. Meteorological conditions used in analyses were north-south and east-west wind momentum, precipitation, and air temperature, and hydrological conditions comprised sea-surface temperature (SST), Palmer Drought Severity Index (PDSI), river flow, and Mississippi River nitrogen to phosphorus $(\mathrm{N}: \mathrm{P})$ ratio.

\section{Materials and methods}

Data sets and sampling locations used to identify responses of juvenile (age 0) and adult (ages 1-6) populations of Gulf menhaden to local meteorological and hydrological conditions imposed by the coupling of AMO and NAO phases and by ENSO events are presented in Table 1 and Figure 1, respectively. Table 1 provides details on periods and sources of climatological, meteorological, hydrological, and biological data used in our analysis of the effect of climate-related factors on the 


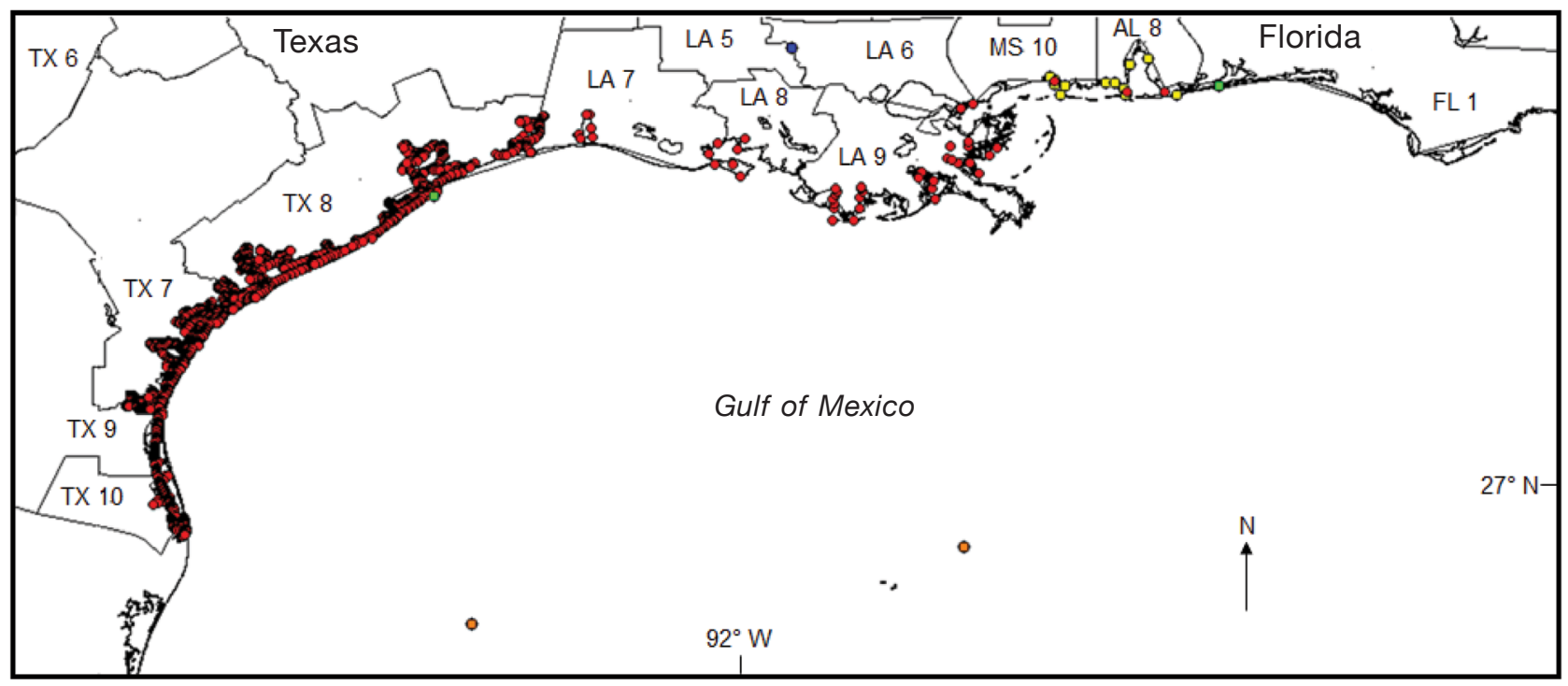

Figure 1

Map of the northern Gulf of Mexico showing the NOAA climate divisions from the western (Texas: TX6-10) and central (Louisiana, LA5-9; Mississippi, MS10; Alabama, AL8; and Florida, FL1) regions, the locations of stations from the U.S. Geological Survey near St. Francisville, Louisiana (1 blue dot seen at boundary between LA5 and LA6), the NOAA National Data Buoy Center (2 orange dots offshore), and the Global Sea Level Observing System (2 green dots), and the sites where biological data were collected with seines (red dots) and beam plankton trawls (yellow dots).

recruitment of menhaden species in the northern Gulf of Mexico. Meteorological and hydrological data were divided into 2 climate areas: central (Louisiana, Mississippi, Alabama, and Florida panhandle) and western (Texas). Annual values of wind momentum (northsouth and east-west directions), SST, and Mississippi River nutrient influx ( $\mathrm{N}: \mathrm{P}$ ratio) were calculated for the months in which larvae of Gulf menhaden inhabit offshore waters. Annual values of air temperature, precipitation, PDSI, and sea level were calculated for the months critical to the inshore growth and development of early life history stages of Gulf menhaden. Annual catch values were calculated by using catch data collected for the months in which juveniles and adults were sampled by fishery-independent and fishery-dependent methods.

The lag in months among AMO, NAO, and ENSO indices and meteorological and hydrological response parameters in offshore waters of the northern GOM (wind momentum and SST), in central and western Gulf Coast regions (air temperature, precipitation, PDSI, and river flow), and in the Mississippi River nutrient influx (N:P ratio) was in agreement with the lag reported by Sanchez-Rubio et al. (2011a). Those authors reported a monthly lag in hydrological responses (e.g., river flow input) in the northcentral GOM to changes in AMO, NAO, and ENSO phases.

\section{Decadal AMO and NAO phases and interannual ENSO events}

For this study, the phases of AMO during the period 1948-2004 and phases of NAO and ENSO during
1950-2004 that were described in Sanchez-Rubio et al. (2011a) were revised, refined, and extended through the use of new AMO (1899-1947), NAO (1899-1949), and ENSO (1895-1949) values from paleontological reconstruction data and new values for all indices (2005-2011) from observational monitoring (see Table 1 for sources of AMO, NAO, and ENSO data). Use of new historical and observational data increased the time period of survey coverage and allowed for more accurate interpretation of climate descriptors. For this study, years classified within phases of AMO, NAO, and ENSO from 1962 to 2010 were considered.

The AMO cold and warm years were defined as years with below-average and above-average SST across the North Atlantic from $0^{\circ}$ to $70^{\circ} \mathrm{N}$ (Enfield et al., 2001). The NAO negative and positive years were defined as years with below-average and above-average meridional oscillation in sea-level pressure between Iceland and the Azores (Hurrell and Van Loon, 1997). The ENSO warm and cold years were defined as years with above-average $\left(>0.75^{\circ} \mathrm{C}\right)$ and below-average $\left(<-0.75^{\circ} \mathrm{C}\right)$ SST in the Niño 3.4 region of the equatorial Pacific, the area defined by $120-170^{\circ} \mathrm{W}$ and from $5^{\circ} \mathrm{S}$ to $5^{\circ} \mathrm{N}$ (Rogers and Coleman, 2003). Years were considered ENSO neutral years when SST deviated between $-0.75^{\circ} \mathrm{C}$ and $0.75^{\circ} \mathrm{C}$ from the average conditions.

The characterization of years within AMO phases described by Sanchez-Rubio et al. (2011a) were modified in this study; years with more than 9 consecutive months of above-average or below-average conditions were characterized as AMO warm or cold years. As a result, the AMO warm year in 1965 (Sanchez- 
Rubio et al., 2011a) was reclassified as an AMO cold year.

The long-term phases of NAO were identified according to the proportion of total number of seasonal values (winter: January-March; spring: April-June; summer: July-September; and fall: October-December) that were negative and positive within a long-term NAO phase. A long-term period with a higher proportion of negative seasonal values was classified as a NAO negative phase, and a long-term period with a higher proportion of positive values was identified as a NAO positive phase. If the NAO negative and positive phases also had negative and positive averaged values, the above classification of phases of NAO was confirmed. The NAO positive $(1959,1995,1996)$ and NAO negative $(1971,1972)$ years classified by Sanchez-Rubio et al. (2011a) were reclassified as NAO negative and NAO positive years, respectively.

The prior classification of ENSO years by SanchezRubio et al. (2011a) was also revised with the new available monthly values of ENSO. To classify a year's event, 3 or more monthly values from May through February were averaged. As a result, the previously classified ENSO cold years in 1971 and 1995 were reclassified as ENSO neutral years.

\section{Meteorological and hydrological data for coastal divisions}

Data sets of monthly precipitation, PDSI, and air temperature were obtained by climate division, the spatial scale by which the NOAA National Climate Data Center divides data from stations within a state. Data sets were acquired for 17 climate divisions along coastal areas from Texas to Florida: Texas (divisions TX610), Louisiana (divisions LA5-9), Mississippi (division MS10), Alabama (division AL8), and Florida (divisions FL1-5). Monthly precipitation (in inches to the hundredths place) and PDSI values were averaged for the water year (defined as September of the current year to August of the subsequent year) from 1899 through 2011. Annual precipitation values were converted into millimeters. Monthly (November-March) air temperature values were averaged across the period 1899-2011.

To compare hydrological conditions (precipitation and PDSI) among climate divisions, single linkage (nearest neighbor) agglomerative clustering based on Pearson correlation coefficients was carried out with SPSS Statistics ${ }^{5}$ software, vers. 20.0 (IBM Corp., Armonk, NY). Three clusters of precipitation and PDSI climate divisions from the eastern (FL2-5), central (LA5-9, MS10, AL8, FL1), and western (TX6-10) regions were found along the Gulf Coast. A Mann-Whitney test was used to test differences among correlation coefficients in groups derived from the cluster analysis. When the null hypothesis of no difference was rejected, annual values of precipitation, PDSI, and air tempera-

\footnotetext{
${ }^{5}$ Mention of trade names or commercial companies is for identification purposes only and does not imply endorsement by the National Marine Fisheries Service, NOAA.
}

ture from grouped climate divisions were averaged to obtain data sets for each variable by region.

For this study, annual environmental data sets were restricted to the western and central regions (from Texas to Alabama) where data were collected for menhaden. Annual regional anomalies were calculated by subtracting the average value by year from the annual value of wind momentum (north-south and east-west directions) and air temperature. Annual values of air temperature (November-March) and sea level (November-May) were taken for the months that corresponded to the recruitment of Gulf menhaden to inshore nursery habitats and to their early juvenile development. Annual values of precipitation, PDSI, and river flow were calculated for the period September-August, the months of early inshore development. Annual regional anomalies were calculated by subtracting the average value by year from the annual value of river flows.

\section{Meteorological and hydrological data: offshore waters}

Hourly SST, wind speed, and wind direction were obtained from offshore monitoring stations (platform 42001, monitored since 1975, and platform 42002, monitored since 1973) maintained by the NOAA National Data Buoy Center (available at website). Hourly values of SST were transformed to daily and monthly values by using averaged values for each of the buoys. To increase the number of available years, we averaged highly correlated (coefficient of correlation $[r]=0.946$, $P<0.001)$ monthly values of SST from buoys at both stations. Because of the potential influence of SST on the development of Gulf menhaden larvae, annual average values of SST were calculated for the spawning season of Gulf menhaden (October of the previous year to March of the following year).

For each of the stations, hourly values of wind direction were used to categorize winds as easterlies, westerlies, northerlies, or southerlies. Wind data from each direction were treated separately. Hourly wind speed data were averaged and transformed to daily and monthly values. Hours of recorded winds from each direction were added to obtain monthly values. Because the sampling hours were different among months, the monthly hours for each direction of the wind were divided by the total monthly hours when wind direction was sampled. Monthly values of wind speed and direction were correlated $(r>0.726, P<0.001)$, and data from both stations were averaged. These data were used to calculate wind stress $(T)$, measured as newtons per square meter:

$$
T=\rho \times C D \times U_{10^{2}}
$$

where $\rho$ (the density of air) $=1.225 \mathrm{~kg} / \mathrm{m}^{3}$;

$U_{10}($ wind speed in $\mathrm{m} / \mathrm{sec})=$ wind speed at $10 \mathrm{~m}$ above the water surface; and

$\mathrm{CD}=$ the drag coefficient for which Smith (1980) proposed a formula to calculate CD:

$$
1000 C D=0.44+\left(0.063 \times U_{10}\right)
$$


The monthly values of $T$ were multiplied by the proportion of monthly hours to obtain wind momentum. To encompass transport-recruitment processes, annual average values of wind momentum (north-south and east-west wind directions) were calculated from October of the previous year to March of the following year, the months when larvae inhabit offshore nursery habitats and early juveniles recruit to estuaries.

\section{Riverine influx of nutrients}

The predicted monthly loads of nutrients for the Mississippi River from October 1974 through September 2011 were obtained from the U.S. Geological Survey (USGS, data available from website). Monthly influx of nutrients (in metric tons) for the mainstem Mississippi River Basin was based on approved water quality data near St. Francisville, Louisiana, and represented stream flows from the Mississippi River at Tarbert Landing, Mississippi, and near Knox Landing, Louisiana, and Thebes, Illinois, and from the Ohio River at Metropolis, Illinois. Monthly concentrations of nutrients were averaged for the water year (September of the previous year to August of the following year). Those months covered the period of early offshore and inshore development of Gulf menhaden. The potential conditions limiting the availability of nutrients were evaluated by calculating the annual average ambient $\mathrm{N}: \mathrm{P}$ ratio in water (Smith, 1984) and by comparing that value with the average value of ambient $\mathrm{N}: \mathrm{P}$ ratio in phytoplankton (Redfield, 1958).

\section{Biological data}

Fishery-independent data on abundances of menhaden postlarvae and juveniles were acquired from BPL samples in Mississippi and Alabama and from seine surveys conducted by state agencies in all the major coastal bay systems of Texas (Texas Parks and Wildlife Commission), Louisiana (Louisiana Department of Wildlife and Fisheries), Mississippi (Mississippi Department of Marine Resources), and Alabama (Alabama Marine Resources monitoring programs) (Table 1). Biological data were analyzed by region (central and western). Within these 2 regions, 19 coastal study areas or bay systems were identified: Lake BorgneChandeleur Sound; Breton Sound; Barataria Bay; Terrebonne-Timbalier Bay; Lake Mechant-Caillou Lake; Vermilion Bay; Calcasieu Lake; Biloxi; Mobile Bay; Sabine Lake; Galveston Bay; Cedar Lakes; East Matagorda Bay; West Matagorda Bay; San Antonio Bay; Aransas Bay; Corpus Christi Bay; Upper Laguna Madre; and Lower Laguna Madre.

Data from seine surveys in Alabama, Mississippi, and Louisiana were grouped into a single data set for the central region (sampling gear and protocols used for surveys in these states are similar and follow those of Christmas [1973]), and data from seine surveys in Texas were placed in the western region. Detailed specifications for seine collections are found in SEDAR. 67891011 In Alabama and Mississippi, smallmesh BPLs with 1.6-mm-mesh wings and a 750-p codend were used, and data from sampling with these BPLs were grouped to form a single data set. The BPL is described in Renfro (1963). Catches in BPL hauls comprised late-stage larvae and postlarvae (11-20 mm standard length [SL]); catches in seine hauls were primarily postlarvae and early juveniles (17-49 $\mathrm{mm}$ SL). According to Shaw et al. (1988), lengths for postlarval Gulf menhaden range between 15 and $25 \mathrm{~mm}$ SL. Transformation to the juvenile stage begins at $\sim 20 \mathrm{~mm}$ SL and ends at $\sim 30 \mathrm{~mm}$ SL (Suttkus, 1956; Hettler, 1984).

Fishery-independent surveys have been conducted in Texas estuaries from 1977 to the present, in Louisiana since 1986, in Alabama since 1981, and in Mississippi from 1973 to the present. Disparity in survey periods, sampling effort, and areal coverage between years and among and within bay systems complicated comparisons of abundance among and within areas in early years with the result that periods of abundance were restricted to those years with adequate sampling coverage and effort. The following years and months were analyzed for this study: seine data, all states, 1985-2008 (January-August); BPL data, Mississippi and Alabama, 1981-2008 (November-May). Yearly catch was calculated by month and gear mentioned above. Annual catch by station within each bay system was calculated by dividing the total catch by the total number of hauls. To obtain yearly catch for each of the 19 bay systems, the annual catches from the stations within a bay system were added and then divided by the number of stations in that system. The catches from bay systems within a region were added and then divided by the number of bay systems within that region to produce a regional annual catch for relevant gear types. Data were analyzed regionally in a manner that ensured equality across each study area (the same weight was given to each station and each bay system).

The purse-seine fishery for menhaden has been in operation since the late 1940s. Gulf menhaden dominate this fishery, and finescale and yellowfin menhaden compose less than $1 \%$ of the annual landing (Ahrenholz, 1981). The fishery is prosecuted from the state

${ }^{6}$ SEDAR (Southeast Data, Assessment, and Review). 2011. Fishery-independent sampling: Alabama. SEDAR27-RD-01, 2 p. [Available at website.]

${ }^{7}$ SEDAR (Southeast Data, Assessment, and Review). 2011. Fishery-independent sampling: Mississippi. SEDAR27RD-02, 5 p. [Available at website.]

8 SEDAR (Southeast Data, Assessment, and Review). 2011. Fishery-independent sampling: Florida SEDAR27-RD-03, 57 p. [Available at website.]

9 SEDAR (Southeast Data, Assessment, and Review). 2011. Fishery-independent sampling: Texas. SEDAR27-RD-04, 11 p. [Available at website.]

10SEDAR (Southeast Data, Assessment, and Review). 2011. Fishery-independent sampling: SEAMAP trawl. SEDAR27RD-05, 6 p. [Available at website.]

${ }^{11}$ SEDAR (Southeast Data, Assessment, and Review). 2011. Fishery-independent sampling: Louisiana. SEDAR27RD-06, 9 p. [Available at website.] 
line between Mississippi and Alabama to as far west as northcentral Texas. Anderson (2007) used mitochondrial DNA to denote a single population in the western GOM and more recent data indicate a single unit stock throughout the northern GOM (Vanderkooy and $\mathrm{Smith}^{4}$ ).

Fishery-dependent data from landings of the reduction purse-seine fishery for Gulf menhaden by age during the period 1964-2010 were obtained from Smith and Vaughan. ${ }^{12}$ Descriptions of the fishery-dependent data and the method used to generate that time series are provided in Vaughan et al. (2007). Total landings of Gulf menhaden, numbers and proportions of fish by age per vessel-ton-week (vtw, defined as the net tonnage of a vessel multiplied by the number of weeks that vessel unloaded fish at least one day (Smith, 1991), were used in this study.

\section{Analyses}

Annual meteorological data (air temperature and north-south and east-west wind stress), hydrological data (precipitation, PDSI, river flow, sea level, SST, and Mississippi River $\mathrm{N}: \mathrm{P}$ ratio) and biological data (fishery-independent age- 0 abundance of Gulf menhaden in the central region and of menhaden species in western region; fishery-dependent numbers and proportions of Gulf menhaden in commercial landings) were compared among decadal regimes associated with the couplings of AMO cold and NAO negative (average regime: 1964-1970), AMO cold and NAO positive (wet regime: 1971-1994), and AMO warm and NAO negative (dry regime: 1995-2010) phases and among interannual regimes associated with ENSO warm events (wet years: 1963, 1965, 1968-1969, 1972, 1976-1977, 1982, 1986-1987, 1991-1994, 1997, 2002, 2004, 2006, 2009), neutral events (average years: 1962, 1966-1967, 1971, 1978-1981, 1985, 1989-1990, 1995-1996, 2001, 2003), and cold events (dry years: 1964, 1970, 19731975, 1983-1984, 1988, 1998-2000, 2005, 2007-2008, 2010). Nonparametric rank-sum tests (Kruskal-Wallis $H$-test, $\chi^{2}$ statistic; Mann-Whitney U-test, $Z$ statistic) were performed with SPSS Statistics, vers. 20.0, on the meteorological, hydrological, and biological responses imposed by the coupling of AMO and NAO phases and by ENSO events. To adjust the $P$-values for multiple comparisons, the alpha level of each individual test was adjusted downward by using the Bonferroni correction method. Linear associations among abiotic variables were checked with the variance inflation factor to quantify the severity of collinearity. This test was performed with linear regression analysis in SPSS, vers. 20.0. To linearize relationships and approximate normality, annual river flows from the western region were logarithmically transformed and annual north-

\footnotetext{
${ }^{12}$ Smith, J. W., and D. S. Vaughan. 2011. Harvest, effort, and catch-at-age for Gulf menhaden. Southeast Data, Assessment, and Review SEDAR 27-DW05, 28 p. [Available at website.]
}

south wind values were cube-root-transformed. All abiotic variables were standardized to a mean of 0 and variance of 1 by subtracting the mean and dividing by the standard deviation.

Two multivariate techniques were used to determine the relationships between abundance of menhaden and climate-related meteorological and hydrological variables. Principal component analysis (PCA) was used on the correlation matrix of abiotic variables to reduce data. The PCA transformed the original set of variables into a smaller set of orthogonal linear combinations of abiotic variables that account for a major portion of the variance in the original set (Chatfield and Collins, 1980; Dillon and Goldstein, 1984). A high number of abiotic variables were reduced to few principal components by using the factor procedure in SPSS Statistics, vers. 20.0. The scree plot was examined to determine where the curve started to flatten between principal components, and only the components with eigenvalues higher than 1 were retained for interpretation. The component scores that were retained were correlated against annual abundances of age-0 Gulf menhaden in BPL and seine hauls in the central region, annual abundances of age- 0 menhaden species in seine hauls in the western region, and annual landings (numbers and proportions) of Gulf menhaden by age from offshore waters of the area studied in the northern GOM.

Because abundance determined with BPL surveys in the central region was not linear, those annual values were cube-root-transformed. Covariability between principal components and biotic variables was examined by performing a Pearson correlation analysis in SPSS Statistics, vers. 20.0. To adjust the $P$-values for multiple correlation analyses, the alpha level of each individual test was adjusted downward with the Bonferroni correction method. In the case of significant correlations, it was assumed that the variables with larger eigenvectors (coefficients of structure or correlations) for the axis were the ones that most influenced the abundance of Gulf menhaden. Further covariability analysis was performed between the actual climaterelated meteorological and hydrological variables and data on fishery-independent catches and fishery-dependent landings of menhaden species. The alpha level of each individual test was also adjusted downward with the Bonferroni correction method.

To identify models of climate-related meteorological and hydrological parameters that contributed to the variability in recruitment of menhaden from Alabama through Texas, the retained component scores were used as predictors of fishery-independent catches (abundances of age-0 Gulf menhaden per BPL or seine haul in the central region and abundances of age- 0 menhaden species per seine haul in the western region) and fishery-dependent landings (numbers and proportions of age-1 Gulf menhaden per vtw) in an automatic linear modeling procedure in SPSS Statistics, vers. 20.0. A predictive model was developed by regressing fishery-independent recruits to age $0\left(R_{0, \mathrm{t}}\right)$ and fishery-dependent recruits to age $1\left(R_{1, \mathrm{t}+1}\right)$ on 
principal components (PC) of climate-related meteorological and hydrological parameters in years $t$ with $t$ equal to 1981-2008 for recruits to age 0 and 1964-2010 for recruits to age 1 ,

$$
\begin{aligned}
R_{0, \mathrm{t}} & =b_{0}+b_{1} P C_{1, \mathrm{t}}+b_{2} P C_{2, \mathrm{t}}+\varepsilon \text { and } \\
R_{1, \mathrm{t}+1} & =b_{0}+b_{1} P C_{\mathrm{t}-1}+b_{2} P C_{2, \mathrm{t}-1}+\varepsilon
\end{aligned}
$$

where $b_{0}, b_{1}$, and $b_{2}$ are estimated parameters; and error $\varepsilon$ is normally distributed $\varepsilon \sim N\left(0, \sigma^{2}\right)$.

To find the best-fitting model, the model selection method of best subsets was used with Akaike's information criterion (AIC; Akaike, 1981). The models with the lowest AIC values were considered most reliable and their coefficients of determination $\left(r^{2}\right)$ were recorded.

\section{Results}

Climate-related meteorological and hydrological regimes and population levels of menhaden

Analyses of fishery-independent data Influence of decadal and interannual climate-related meteorological and hydrological regimes on early juveniles of Gulf menhaden was evident. Early juvenile abundances from the BPL surveys in the central region $(\mathrm{Z}=-2.212, P=0.027$; Fig. $2 \mathrm{~A}$ ) and the N:P ratio of the Mississippi River influx $(\mathrm{Z}=-2.520, P=0.012$; Fig. $2 \mathrm{~B}$ ) were higher during the decadal wet regime than during the decadal dry regime. During the wet regime, Mississippi River waters had an average N:P ratio closer to the Redfield (1958) ratio of $16: 1$, a ratio that indicates no limitation in $\mathrm{N}$. During the dry regime, Mississippi River waters had an average $\mathrm{N}: \mathrm{P}$ ratio of less than 10 , a value that usually indicates conditions under which phytoplankton production is nitrogen limited (Ram and Plotkin, 1983; Sakshaug and Olsen, 1986).

Abundance of early juveniles from seine surveys was higher in the central region than in the western region (Texas, $Z=-5.938, P<0.001$ ), supporting the need for a regional analysis of data. Mean ranks of seine catches $\left(\chi^{2}=8.814, P=0.012\right)$ and air temperature $\left(\chi^{2}=7.066\right.$, $P=0.029)$ in the western region and of PDSI in the central and western regions $\left(\chi^{2}>9.858, P<0.007\right)$ were different among ENSO events. Seine catches of early juveniles in the western region $(Z<-2.441, P<0.016$; Fig. 3A) and of PDSI in the central region $(Z<-2.620$, $P<0.010$; Fig. 3B) were higher during wet and average ENSO years than during dry ENSO years. In addition, PDSI in the western region was higher during wet ENSO years than during dry ENSO years $(Z=-2.928$, $P=0.003$; Fig. 3C).

With principal component analysis we extracted 5 components of climate-related meteorological and hydrological parameters associated with BPL catches of Gulf menhaden (Table 2). Correlation analysis of BPL catches with the 5 extracted principal components showed that catches of early juvenile Gulf menhaden

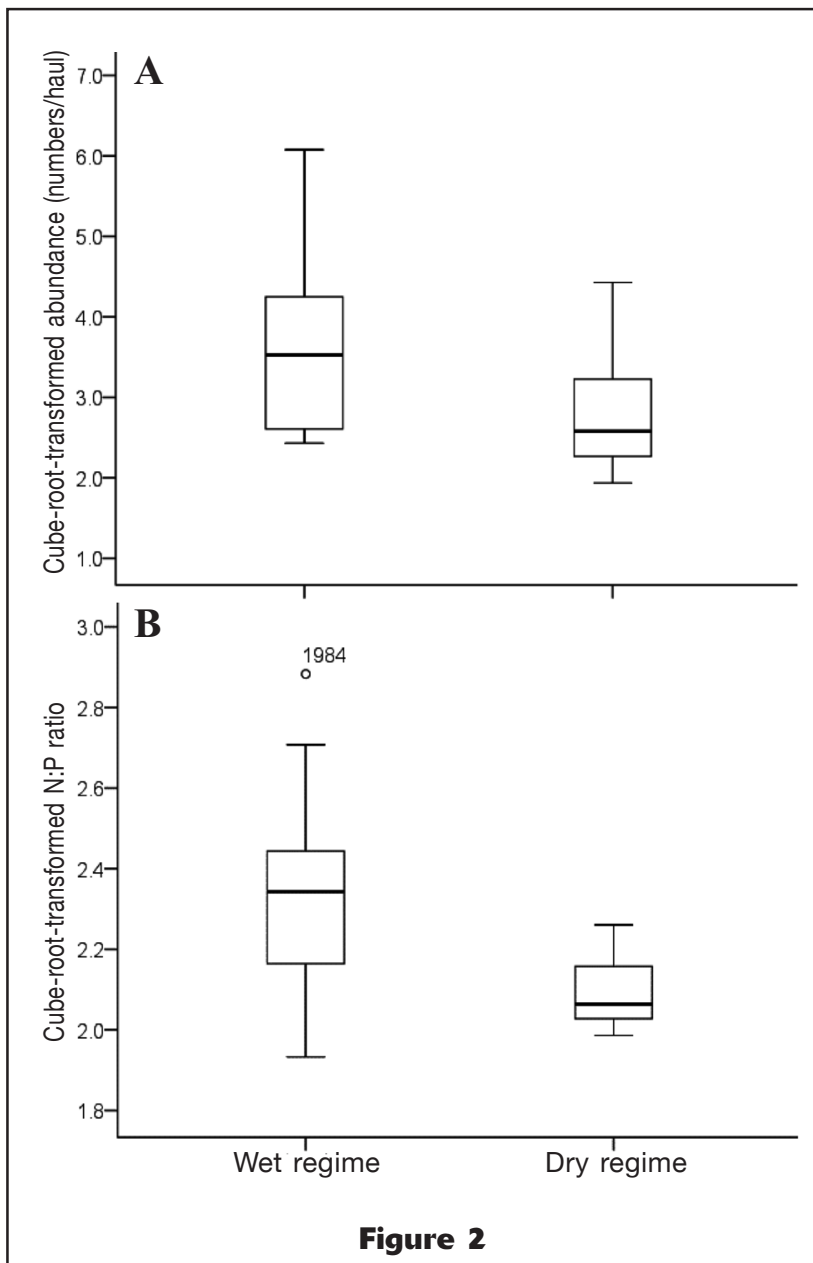

Box plots of (A) cube-root-transformed abundance of postlarval Gulf menhaden (Brevoortia patronus) in beam plankton trawl (BPL) surveys, measured as numbers per BPL haul (1981-2008), and (B) cube-root-transformed $\mathrm{N}: \mathrm{P}$ ratio of the Mississippi River influx in the central region of the Gulf Coast (1981-2008) under 2 contrasting climate-related hydrological regimes: the wet regime, or the cold phase of the Atlantic Multidecadal Oscillation (AMO) and the positive phase of the North Atlantic Oscillation (NAO) in 1981-1994, and the dry regime, or the AMO warm-NAO negative phase in 1995-2008. Horizontal lines for each box plot indicate the 5th, 25th, 50 th (median), 75th, and 95th percentiles. Outliers are shown as dots, and they are labeled by year.

in BPL hauls in the central region were correlated with the third $(r=-0.494, P=0.010)$ and fifth $(r=0.624$, $P=0.001)$ extracted components. In order of importance, the variables loaded on the third extracted component were air temperature from the central region, northsouth and east-west wind directions from offshore waters, NAO from the North Atlantic Ocean, air temperature from the western region, river flow from the central region, and PDSI and precipitation from the western region. In order of importance, the variables loaded on the fifth component extracted were cube- 


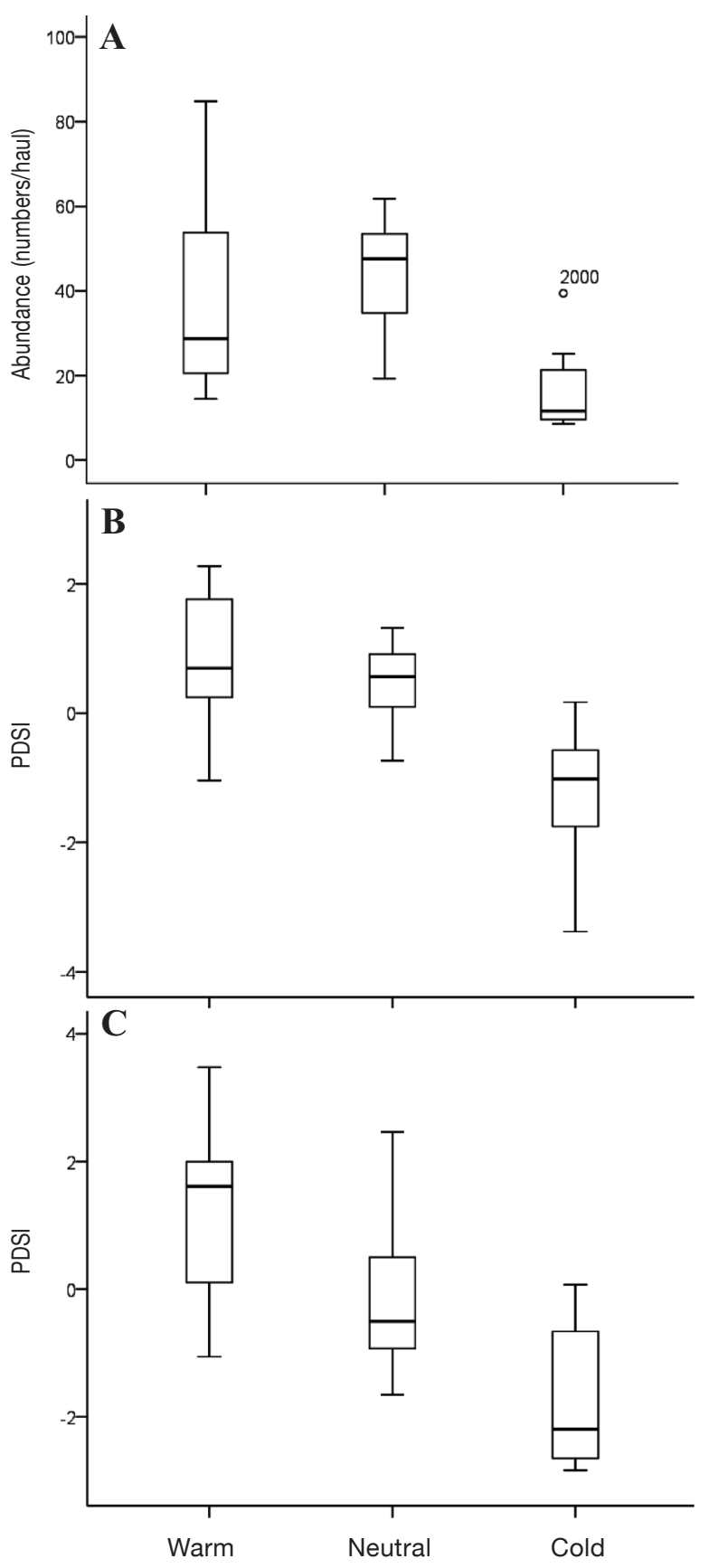

Figure 3

Box plots of (A) abundance of early juveniles of menhaden species in seine surveys, measured as numbers per haul, in the western region of the Gulf Coast and Palmer Drought Severity Index (PSDI) in the (B) central and (C) western regions during the period 19852008 under interannual hydrological events associated with the El Niño Southern Oscillation (ENSO). Horizontal lines for each box plot indicate the 5th, 25th, 50 th (median), 75th, and 95th percentiles. Outliers are shown as dots, and they are labeled by year. root-transformed N:P ratio of Mississippi River influx and north-south wind direction. Correlation analysis of BPL catches with the actual environmental variables showed that catches in the BPL hauls were correlated with the cube-root-transformed Mississippi River N:P ratio ( $r=0.670, P<0.001$ ). Although numbers of early juveniles in seine hauls were not related to any of the extracted components, abundances of early juveniles in seine hauls in the western region were correlated with cube-root-transformed Mississippi River N:P ratio $(r=0.591, P=0.002)$. These results indicate that high (3.6/BPL haul) abundances of age-0 Gulf menhaden from BPL hauls in the central region and high (38.3/ seine haul) abundances of age-0 menhaden species from seine hauls in the western region were found during periods of a high (2.3) N:P ratio of Mississippi River influx.

Multiple regression analyses were performed between abundance of Gulf menhaden from fishery-independent BPL surveys and the 5 extracted components. According to the regression models developed from AIC, 2 significant predictors (third and fifth components) with negative and positive regression coefficients, respectively, explained $60 \%$ of the variance contained in cube-root-transformed BPL catches of early juvenile Gulf menhaden (Table 3, Fig. 4A). These results indicate that the variability in abundance of age-0 Gulf menhaden was partially explained by climate-related meteorological and hydrological conditions in the northern GOM.

Analyses of fishery-dependent data Mean ranks of commercial harvest (numbers and proportions of age-1 Gulf menhaden; $\left.\chi^{2}>7.340, \mathrm{P}<0.026\right)$ and climate-related hydrological parameters (precipitation, PDSI, river flow, and sea level in the central region and sea level in the western region; $\chi^{2}>6.041, P<0.05$ ) were different among the coupling of AMO and NAO phases. Proportions of age-1 Gulf menhaden in landings $(\mathrm{Z}=-2.982, P=0.003$; Fig. 5A), PDSI ( $\mathrm{Z}=-2.429, P=0.015$; Fig. 5B), and river flow $(Z=-2.595, P=0.009$; Fig. 5C) in the central region were higher during the decadal wet regime than during the decadal dry regime. Numbers $(Z=-2.673, P=0.008$; Fig. 6A) and proportions $(\mathrm{Z}=-3.274, P=0.001$; Fig. $5 \mathrm{~A})$ of age-1 fish in landings were higher during the decadal average regime than during the dry regime, but sea level $(Z<-2.672, P<0.009)$ in the western (Fig. 6B) and central (Fig. 6C) regions was lower during the decadal average regime than during the dry regime.

Principal component analysis revealed 3 components of climate-related meteorological and hydrological parameters associated with Gulf menhaden commercial landings (Table 4). Correlation analysis of commercial landings with the 3 extracted principal components showed that landings of age-1 Gulf menhaden were correlated with 1 of the 3 extracted components. Numbers $(r=-0.689, P=0.000)$ and proportions $(r=-0.571$, $P=0.000)$ of age-1 Gulf menhaden were correlated with the second component. In order of importance, the variables loaded on the second extracted component were 


\section{Table 2}

The 5 extracted principal components of climate-related meteorological and hydrological variables that are considered to have influenced the variability of catches of Gulf menhaden (Brevoortia patronus) in beam plankton trawl (BPL) surveys from 1981 through 2008 in the northern Gulf of Mexico. E-W=east-west; N-S=north-south; $\mathrm{N}: \mathrm{P}=$ nitrogen to phosphorus ratio. Data were divided into 2 climate regions: central (Louisiana, Mississippi, Alabama, and Florida panhandle) and western (Texas).

\begin{tabular}{|c|c|c|c|c|c|c|}
\hline \multirow[b]{2}{*}{ Regions } & \multirow[b]{2}{*}{ Variables } & \multicolumn{5}{|c|}{ Extracted principal components } \\
\hline & & $1^{\text {st }}$ & $2^{\text {nd }}$ & $3^{\text {rd }}$ & $4^{\text {th }}$ & $5^{\text {th }}$ \\
\hline North Atlantic & North Atlantic Oscillation & 0.467 & & 0.549 & & \\
\hline \multirow{2}{*}{ Offshore waters } & $\mathrm{E}-\mathrm{W}$ wind direction & & 0.408 & -0.592 & 0.308 & \\
\hline & $\mathrm{N}-\mathrm{S}$ wind direction & & & -0.635 & 0.474 & -0.356 \\
\hline \multirow{6}{*}{ Central region } & Cube-root-transformed N:P ratio & & -0.375 & & 0.479 & 0.761 \\
\hline & Sea level & 0.535 & & & 0.585 & \\
\hline & River flow & 0.583 & -0.494 & 0.469 & & \\
\hline & Precipitation & 0.795 & -0.372 & & & \\
\hline & Palmer Drought Severity Index & 0.771 & -0.419 & & & \\
\hline & Air temperature & & 0.666 & 0.684 & & \\
\hline \multirow[t]{8}{*}{ Western region } & Precipitation & 0.788 & & -0.314 & & \\
\hline & Palmer Drought Severity Index & 0.822 & & -0.378 & & \\
\hline & Cube-root-transformed river flow & 0.663 & 0.398 & & -0.439 & \\
\hline & Air temperature & & 0.760 & 0.482 & & \\
\hline & Sea level & 0.611 & 0.638 & & 0.327 & \\
\hline & Eigenvalue & 4.269 & 2.605 & 2.433 & 1.368 & 1.008 \\
\hline & Variance explained (\%) & 30.489 & 18.604 & 17.377 & 9.774 & 7.203 \\
\hline & Cumulative variance explained (\%) & 30.489 & 49.093 & 66.470 & 76.244 & 83.447 \\
\hline
\end{tabular}

air temperature from the western and central regions, sea level from the western and central regions, and PDSI from the western region.

Correlation analysis of commercial landings with environmental variables showed that numbers and proportions of age- 1 Gulf menhaden were correlated with air temperature and sea level in the western region $(r<$ $-0.485, P<0.002)$ : high numbers (10 million fish/vtw) and proportions $(74 \% / v t w)$ were found during periods of low $\left(0.87^{\circ} \mathrm{C}\right.$ below average $)$ air temperature and (6954 mm) sea level. Low (6.2 million fish/vtw) numbers of age- 1 Gulf menhaden were correlated with high $\left(0.47^{\circ} \mathrm{C}\right.$ above average) air temperature and $(7258 \mathrm{~mm})$ sea level $(r<-0.446, P<0.003)$ in the central region. High $(74 \% / v t w)$ proportions of age-1 Gulf menhaden in fishery landings were correlated with AMO cold years ( $r=-0.497, P=0.000)$.

Multiple regression analyses were performed to determine which of the 3 extracted components individually or combined best resembled the variability of fishery-dependent landings of Gulf menhaden. According to the regression models developed from AIC, a significant predictor (second component) with a negative regression coefficient explained $46 \%$ of the variance contained in the numbers of age-1 Gulf menhaden (Table 3, Fig. 4B). In addition, 2 significant predictors (first and second components) with positive and negative regression coefficients, respectively, explained $34 \%$ of the variance contained in the proportion of age- 1 Gulf menhaden in landings (Table 3, Fig. 4C).

\section{Discussion}

Differences in responses of menhaden to decadal and annual meteorological and hydrological regimes were evident in this study, providing additional support for the notion that climate plays a role in structuring suitable habitat and, therefore, in survival of larvae and juveniles of menhaden. The specific meteorological and hydrological conditions identified as determinates of abundance estimates, however, differed from those identified in past studies. We found that a high recruitment of menhaden postlarvae (3.6/BPL haul), juveniles (38.3/seine haul), and age-1 fish in landings (10 million/vtw) was associated with cold, wet spawning and recruitment seasons characterized by high PDSI (0.45) and coastal river flow (401.6 $\mathrm{m}^{3} / \mathrm{s}$ above average), by a Mississippi River $\mathrm{N}: \mathrm{P}$ ratio of 2.3 , and by low sea level $(7065 \mathrm{~mm})$; low recruitment occurred in warm, dry seasons. In contrast, Guillory et al. (1983) found that elevated juvenile recruitment was associated with cold, dry winters and poor recruitment with warm, wet winters. Contradictory results between studies may be related to 1) differences in data selected for analysis, 2) gear types and associated differences in life history stages and habitats, and 3) spatial and temporal differences in the characterization of meteorological and hydrological conditions that drive recruitment of menhaden species.

Data reviewed in the Guillory et al. (1983) and Govoni (1997) studies span what the authors described as 


\section{Table 3}

Linear models fitted to fishery-independent and fishery-dependent data on Gulf menhaden (Brevoortia patronus) in the northern Gulf of Mexico during the periods from 1981 through 2008 and from 1964 through 2010, respectively. BPL=beam plankton trawl; vtw=vessel ton week in the purse-seine fishery; $F=F$-test; $r^{2}=$ coefficient of determination; AIC=Akaike's information criterion. Adjusted $r^{2}$ would be sufficient.

\begin{tabular}{|c|c|c|c|c|c|c|c|c|c|}
\hline Model & Response variables & $\begin{array}{l}\text { Explanatory } \\
\text { variables }\end{array}$ & $\mathrm{df}$ & $\begin{array}{l}\text { Sum of } \\
\text { squares }\end{array}$ & $F$ & $P(>F)$ & $r^{2}$ & AIC & $\begin{array}{c}\text { Adjusted } \\
r^{2}\end{array}$ \\
\hline 1 & $\begin{array}{l}\text { cube-root-transformed } \\
\text { abundance per } \\
\text { BPL haul }\end{array}$ & $\begin{array}{l}5^{\text {th }} \text { component } \\
3^{\text {rd }} \text { component } \\
\text { Intercept }\end{array}$ & $\begin{array}{l}1 \\
1\end{array}$ & 15.568 & 19.841 & 0.000 & $\begin{array}{r}0.679 \\
-0.493 \\
3.219\end{array}$ & -21.5 & $\begin{array}{l}0.62 \\
0.21\end{array}$ \\
\hline 2 & $\begin{array}{l}\text { Age-1 landing } \\
\text { per vtw }\end{array}$ & $\begin{array}{l}2^{\text {nd }} \text { component } \\
\text { Intercept }\end{array}$ & 1 & 230.728 & 40.740 & 0.000 & $\begin{array}{r}-2.240 \\
7.657\end{array}$ & 83.7 & 0.46 \\
\hline 3 & $\begin{array}{l}\text { Age-1 proportion } \\
\text { of total landings } \\
\text { per vtw }\end{array}$ & $\begin{array}{l}2^{\text {nd }} \text { component } \\
1^{\text {st }} \text { component } \\
\text { Intercept }\end{array}$ & 1 & 0.501 & 12.344 & 0.000 & $\begin{array}{r}-0.100 \\
0.032 \\
0.572\end{array}$ & -179.7 & $\begin{array}{l}0.33 \\
0.01\end{array}$ \\
\hline
\end{tabular}

2 climate periods, a series of years of low river flows followed by years of high river flows. Sanchez-Rubio et al. (2011a) and Sanchez-Rubio and Perry, ${ }^{13}$ using climatic indices that spanned the time period preceding and during the low river flow conditions of Guillory et al. (1983) and high river flow period of Govoni (1997), characterized the years during their studies as average (1964-1970) and high (1971-1994) river flow periods. The high river flow regime ended in 1994 and was followed by low river flow conditions brought on by a change in the phases of AMO and NAO in 1995 (Sanchez-Rubio and Perry ${ }^{13}$ ).

At the decadal scale, Govoni (1997) found increased numbers of Gulf menhaden under conditions of high river flow in the years following 1975. He attributed this increase to enhanced nutrient availability and suggested "discharge of the Mississippi River was positively associated with recruitment over decadal scales." A relationship between decadal oscillations of Mississippi River flow and abundance of another estuarine organism, the blue crab (Callinectes sapidus), was reported by Sanchez-Rubio et al. (2011b). Both blue crab and Gulf menhaden in northern GOM estuaries appear to respond positively to wet regimes, although the factors responsible for driving abundances differ between the 2 species. Decreased predation, associated with a reduced predator guild in waters with lowered salinities, was found to be responsible for increased numbers of juvenile blue crab during wet regimes. In this study, decadal abundance of early juvenile Gulf menhaden in the BPL surveys was higher during the decadal cold,

\footnotetext{
${ }^{13}$ Sanchez-Rubio, G., and H. Perry. 2013. Climate-related meteorological and hydrological regimes and their influence on Gulf menhaden (Brevoortia patronus) recruitment in the northern Gulf of Mexico: final administrative report, $30 \mathrm{p}$. Saltonstall-Kennedy project no. NA10NMF4270195. [Available from Office of Management and Budget, Natl. Mar. Fish. Serv., NOAA, 1315 East-West Hwy., Silver Spring, MD.]
}

wet regime (throughout the coupling of AMO cold and NAO positive phases) characterized by high (2.3) cuberoot-transformed N:P ratio of Mississippi River influx than during other considered regimes.

The importance of nutrients to recruitment was evident in this study. The Mississippi River N:P ratio and north-south wind direction explained $41 \%$ of variability in abundance of early juvenile Gulf menhaden. In Louisiana, northerly winds produce extremely low tides, high transport of organic material into open waters, and strong upwelling events (Moeller et al., 1993). The contribution of other environmental factors, such as NAO, east-west wind direction in offshore waters, air temperature and river flow in the central region, and PDSI, precipitation, and air temperature in the western region, accounted for $21 \%$ of the variability.

Commercial landings also showed decadal fluctuations in the proportion of age-1 Gulf menhaden in relation to the total landings, measured as numbers of fish per vtw. The proportion of age-1 Gulf menhaden in the catch (Alabama-Texas) was significantly higher during the decadal cold, wet regime characterized by high (0.56) values of PDSI and high $\left(401.6 \mathrm{~m}^{3} / \mathrm{s}\right.$ above average) river flows in the central region than during the decadal warm, dry regime. A decrease in both early juvenile abundance (fishery-independent surveys) and the proportion of age- 1 fish in the commercial landings occurred with the 1995 shift in climate regimes from cold and wet to warm and dry, indicating diminished recruitment over the warm, dry period. Although the abundance of age- 1 fish in commercial landings decreased, the numbers of Gulf menhaden of ages 2-6 remained stable with a slight increase observed for age-2 fish (Vanderkooy and Smith ${ }^{4}$ ). The increase in numbers and relative stability of age- 2 fish in commercial landings indicated continued recruitment to the fishery. 


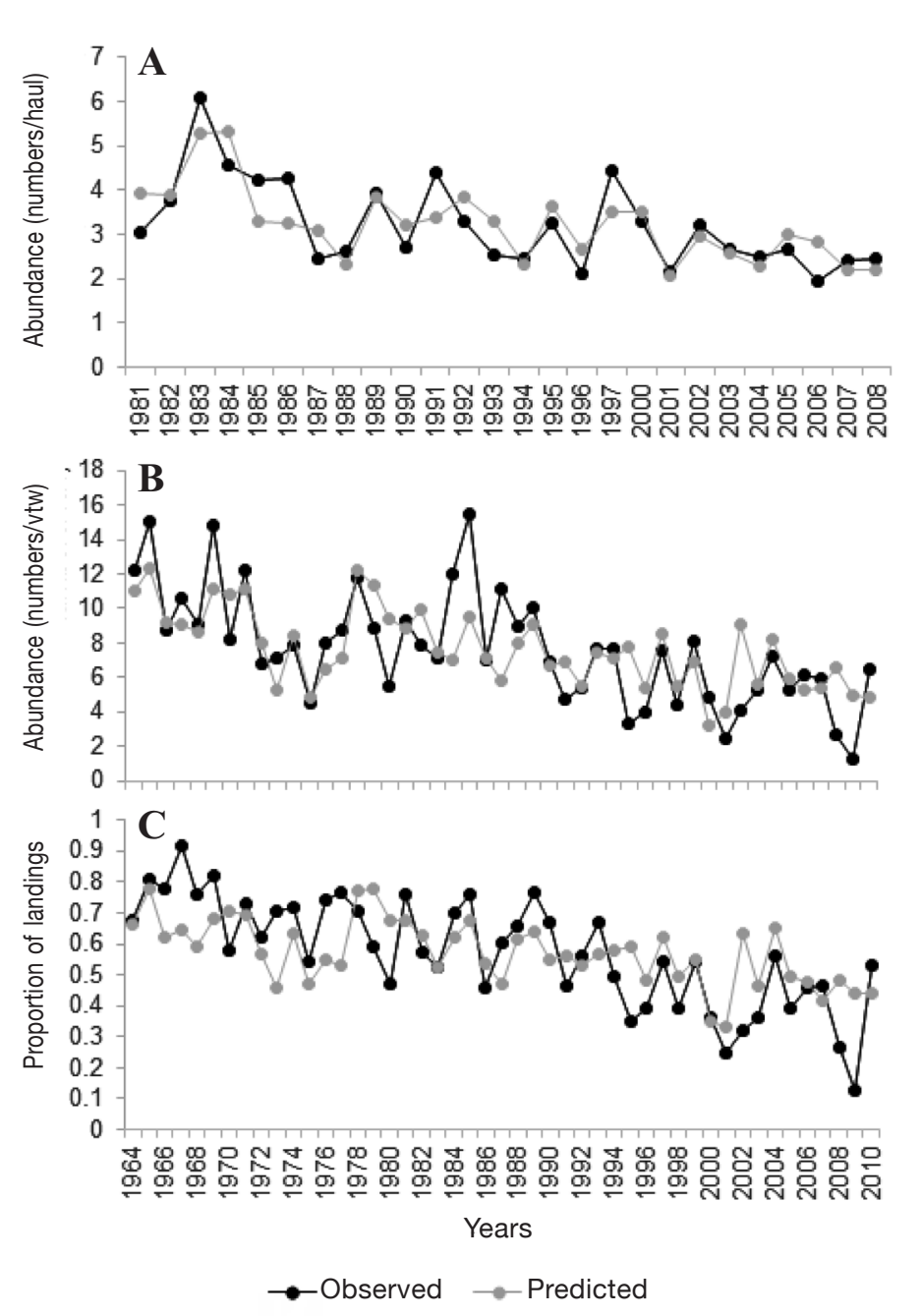

Figure 4

Observed (black line) and predicted (gray line) yearly values for (A) numbers of postlarval Gulf menhaden (Brevoortia patronus) in surveys conducted with beam plankton trawls (BPLs) during 1981-2008 in Mississippi and Alabama, (B) numbers of age-1 Gulf menhaden in commercial landings (millions of fish per vessel-ton/ week [vtw]), and (C) proportion of age-1 Gulf menhaden in landings per vtw taken in the purse-seine fishery in the northern Gulf of Mexico in 1964-2010.

The steady decreases in age- 0 and -1 Gulf menhaden that have been observed since 1964 may have been a function of the fishery-dependent and fishery-independent sampling strategies and changes in the physiography of nearshore environments in the northern GOM. Fixed fishery-independent sampling stations may account for some portion of the perceived decline in abundance of early juvenile Gulf menhaden as fish moved farther up into estuaries in response to elevated salinities (Vanderkooy and $\mathrm{Smith}^{4}$ ). The downward trend of age-1 Gulf menhaden in commercial landings (numbers and proportions) from 1964 to 2010 was accompanied by a steady rise of sea level in the study area. Num- bers and proportions of age- 1 Gulf menhaden in commercial landings were high (10 million fish/vtw; 74\%/vtw) during the decadal average hydrological regime characterized by low $(6954 \mathrm{~mm})$ sea level. Proportion of age-1 Gulf menhaden in commercial landings was average $(61 \% / v t w)$ during the decadal cold, wet regime characterized by high (0.56) PDSI and high (401.6 above average) river flows. Numbers and proportions of age-1 Gulf menhaden in commercial landings were low (6.2 million fish/vtw; 44\%/vtw) during the decadal warm, dry regime with high $(7016 \mathrm{~mm})$ sea level, low (-0.57) PDSI, and low (247.6 belowaverage) river flows.

Changes in the physiography of estuaries due to sea level rise and conversion of wetlands to open water may play a major role in structuring inshore nursery habitats for Gulf menhaden, and declining numbers of age-1 fish in the commercial harvest may reflect a response to those changes. The stable numbers of age- 2 fish in the commercial harvest indicate that age- 1 Gulf menhaden were remaining in nearshore waters and entering the fishery at a later age $\left(\mathrm{SEDAR}^{3}\right)$. Air temperature and sea level in the western and central regions and PDSI in the western region explained $46 \%$ and $32 \%$ of the variability in numbers and proportions of age-1 Gulf menhaden. Only an additional $1 \%$ of the variability in proportion of age- 1 Gulf menhaden was explained by adding meteorological and hydrological factors, such as PDSI from the central region and precipitation and river flows from the central and western regions.

The influence of Mississippi River discharge on annual recruitment of Gulf menhaden has been analyzed over the last 30 years. Previous studies found an inverse annual association between Mississippi River discharge (November-March) and estimates of juvenile recruits (Guillory et al., 1983; Govoni, 1997; Vaughan et al., 2000, 2007). Govoni (1997) explained this relationship by suggesting that high flow of the Mississippi River and the resultant plume pushed larvae farther offshore, prolonging shoreward transport of larvae and increasing larval vulnerability to predation. Results of this study indicate a positive association between ENSOrelated meteorological (e.g., northerly cold winds) and hydrological (e.g., river discharge and flooding events) conditions and the recruitment of Gulf menhaden-a finding that is contradictory to the results of these previous studies.

The influence of ENSO on recruitment of Gulf menhaden can be explained by its effect in structuring suitable offshore and inshore nursery habitats. In offshore waters, high seaward projection and areal coverage of the nutrient-rich plume of the Mississippi River are 


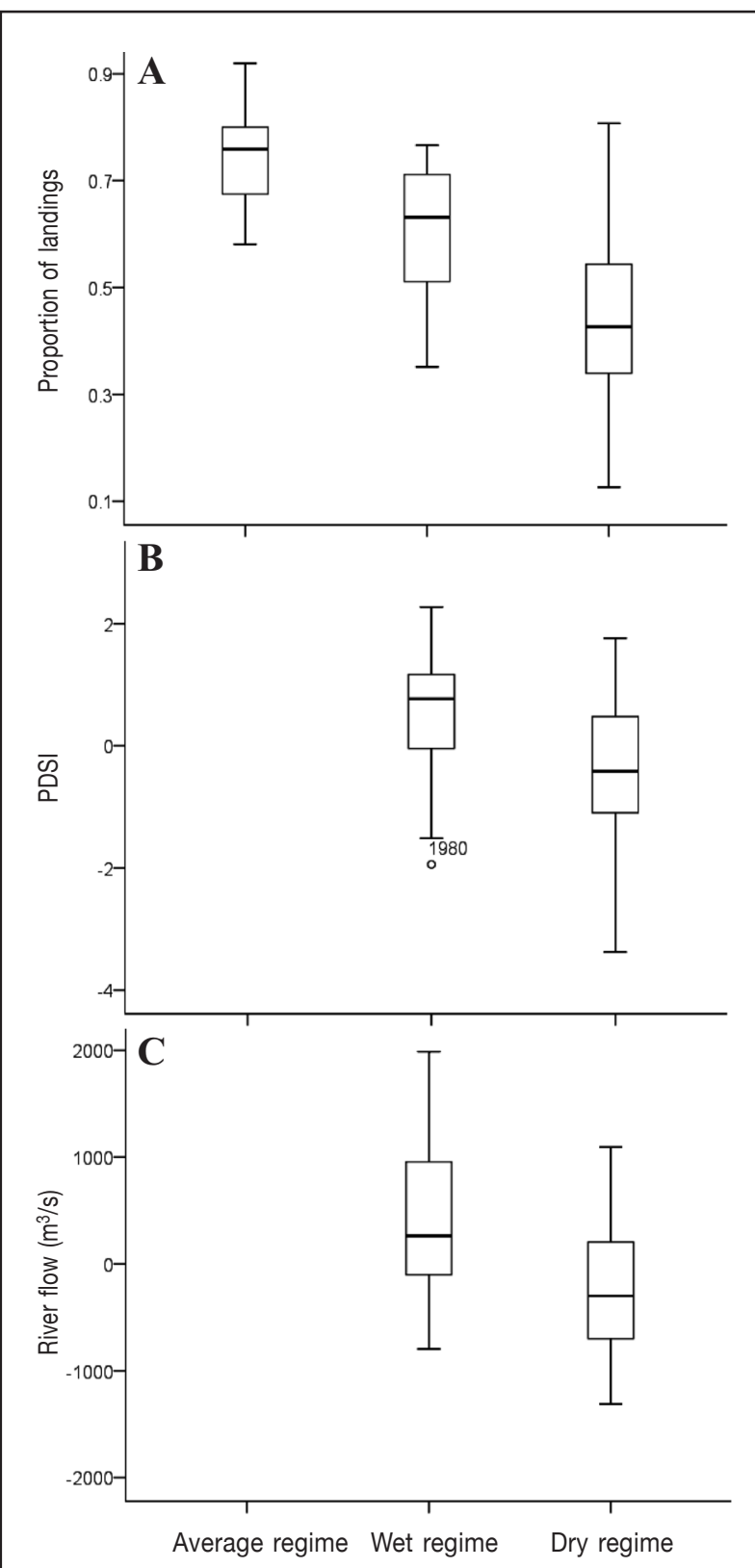

Figure 5

Box plots of (A) proportion of age-1 Gulf menhaden (Brevoortia patronus) in total landings per vesselton-week (vtw) in the purse-seine fishery, (B) Palmer Drought Severity Index (PSDI), and (C) river flow in the central region during the 3 dominant climate-related hydrological regimes in the Gulf of Mexico: average regime, or the AMO cold-NAO negative phase in 1964-1970; wet regime, or the cold phase of the Atlantic Multidecadal Oscillation (AMO) and the positive phase of the North Atlantic Oscillation (NAO) in 1971-1994; and dry regime, or the AMO warm-NAO negative phase in 1995-2010. Horizontal lines for each box plot indicate the 5 th, 25 th, 50 th (median), 75 th, and 95 th percentiles. Outliners are shown as dots and they are labeled by year.

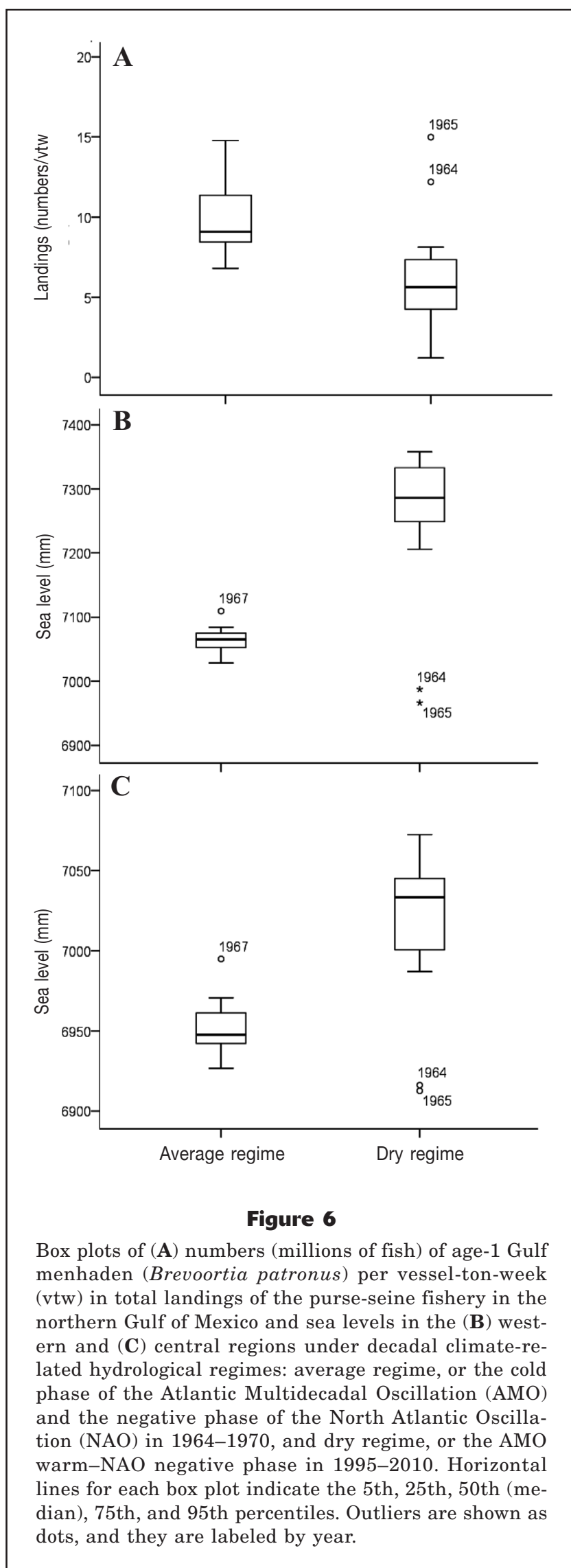




\section{Table 4}

The 3 extracted principal components of climate-related meteorological and hydrological variables that are considered to have influenced the variability of commercial landings (numbers and proportions per vessel ton week) of Gulf menhaden (Brevoortia patronus) from 1964 through 2010 in the northern Gulf of Mexico. Data were divided into 2 climate regions: central (Louisiana, Mississippi, Alabama, and Florida panhandle) and western (Texas).

\begin{tabular}{llcrr}
\hline \multirow{2}{*}{ Regions } & & \multicolumn{2}{c}{ Extracted principal components } \\
\cline { 3 - 4 } Central region & Variables & $1^{\text {st }}$ & $2^{\text {nd }}$ & $3^{\text {rd }}$ \\
& Precipitation & 0.776 & & -0.459 \\
& Palmer Drought Severity Index & 0.740 & & -0.463 \\
& River flow & 0.719 & & -0.563 \\
& Air temperature & 0.342 & 0.855 & \\
& Sea level & 0.727 & 0.533 & \\
& & & & \\
Western region & Palmer Drought Severity Index & 0.714 & -0.381 & 0.500 \\
& Air temperature & & 0.940 & \\
& Sea level & 0.651 & 0.578 & 0.575 \\
& Precipitation & 0.689 & & 0.559 \\
& Cube-root-transformed river flow & 0.673 & & 1.660 \\
& Eigenvalue & 4.173 & 2.648 & \\
& Variance explained (\%) & 41.734 & 26.482 & 16.596 \\
& Cumulative variance explained (\%) & 41.734 & 68.216 & 84.812 \\
& & & & \\
\hline
\end{tabular}

driven by the strong, coastal upwelling and high river flow associated with meteorological (e.g., frequency of cold fronts and, therefore, low air temperatures associated with northerly winds; Henderson and Vega, 1996) and hydrological (e.g., precipitation; Douglas and Englehart, 1981) conditions related to the warm phase of ENSO. These conditions have the potential to enhance larval development and survival of Gulf menhaden (Riley, 1937; Dagg and Whitledge, 1991; Grimes and Finucane, 1991; Hitchcock et al., 1997). In the intertidal zone, extreme winter low tides and cold temperatures associated with meteorological (e.g., northerly cold winds and cold fronts; Henderson and Vega, 1996) conditions related to the ENSO warm phase produce an accumulation of detritus through the die off of marsh grasses (Kirby, 1972; Day et al., 1973). In spring, plant detritus collected during the winter is washed to open waters by flooding events produced by the prevailing southeasterly winds. During this season, juveniles move from the intertidal zone to open waters, where the availability of detritus as a food source becomes crucial for their development and survival (Darnell, 1958).

\section{Acknowledgments}

The authors thank V. Guillory, K. Ibos, J. Adriance, P. Cook, and M. Harbison from the Louisiana Department of Wildlife and Fisheries, F. Martinez-Andrade from the Texas Parks and Wildlife Department, L. Hartman from the Marine Resources Division of the Alabama Department of Conservation and Natural Resources, and J. Anderson from the Center for Fisheries Research and Development at the Gulf Coast Research Laboratory, University of Southern Mississippi for providing us with the fishery-independent data used in this study. Commercial landings data were furnished by D. Vaughan and J. Smith of the National Marine Fisheries Service, NOAA. Data used in this publication was assimilated under NOAA 2010 Saltonstall-Kennedy Grant NA10NMF4270195: climate-related hydrological regimes and their influence in Gulf menhaden recruitment in the northcentral GOM.

\section{Literature cited}

Ahrenholz, D. W.

1981. Recruitment and exploitation of Gulf menhaden, Brevoortia patronus. Fish. Bull. 79:325-335.

Akaike, $\mathrm{H}$.

1981. Likelihood of a model and information criteria. J. Econometrics 16:3-14. Article

Anderson, J. D.

2007. Systematics of the North American menhadens: molecular evolutionary reconstructions in the genus Brevoortia (Clupeiformes: Clupeidae). Fish. Bull. 105:368-378.

Anderson, J. D., and W. J. Karel.

2014. Limited genetic structure of Gulf Menhaden (Brevoortia patronus), as revealed by microsatellite markers developed for the genus Brevoortia (Clupeidae). Fish. Bull. 112:71-81. Article

Boschung, H. T. Jr., R. L. Mayden, and J. R. Tomelleri.

2004. Fishes of Alabama, 960 p. Smithsonian Books, Washington, D.C. 
Bratkovich, A., S. P. Dinnel, and D. A. Goolsby.

1994. Variability and prediction of freshwater and nitrate fluxes for the Louisiana-Texas shelf: Mississippi and Atchafalaya River source functions. Estuaries 17:766-778. Article

Chatfield, C., and A. J. Collins.

1980. Introduction to multivariate analysis, $246 \mathrm{p}$. Chapman and Hall, London.

Christmas, J. Y.

1973. Area description: phase I. In Cooperative Gulf of Mexico estuarine inventory and study, Mississippi (J. Y. Christmas, ed.), p. 1-71. Gulf Coast Research Laboratory. Ocean Springs, MS.

Christmas, J. Y., J. T. McBee, R. S. Waller, and F. C. Sutter III. 1982. Habitat suitability models: Gulf menhaden. U.S. Dep. Int. Fish Wildl. Serv. FWS/OBS 82/10.23, 23 p. [Available at website.]

Christmas, J. Y., and R. S. Waller.

1973. Mississippi: estuarine vertebrates. In Cooperative Gulf of Mexico estuarine inventory and study, Mississippi (J. Y. Christmas, ed.), p. 320-434. Gulf Coast Research Laboratory, Ocean Springs, MS.

Cochrane, J. D., and F. J. Kelly.

1986. Low-frequency circulation on the Texas-Louisiana shelf. J. Geophys. Res., C 91:10645-10659. Article

Dagg, M. J., and T. E. Whitledge.

1991. Concentrations of copepod nauplii in the nutrientrich plume of the Mississippi River. Cont. Shelf Res. 11:1409-1423. Article

Darnell, R. M.

1958. Food habits of fishes and larger invertebrates of Lake Pontchartrain, Louisiana, an estuarine community. Publ. Inst. Mar. Sci., Univ. Texas 5:353-416.

Day, J. W. Jr., W. G. Smith, P. Wagner, and W. Stowe.

1973. Community structure and carbon budget in a salt marsh and shallow bay estuarine system in Louisiana. Sea Grant Publ. LSU-SG-72-04, 80 p. Cent. Wetland Resour., Louisiana State Univ., Baton Rouge, LA.

Deegan, L. A.

1986. Changes in body composition and morphology of young-of-the-year gulf menhaden, Brevoortia patronus Goode, in Fourleague Bay, Louisiana. J. Fish Biol. 29:403-415. Article

1990. Effects of estuarine environmental conditions on population dynamics of young-of-the-year gulf menhaden. Mar. Ecol. Prog. Ser. 68:195-205.

Deegan, L. A., and B. A. Thompson.

1985. The ecology of fish communities in the Mississippi River deltaic plain. In Fish community ecology in estuaries and coastal lagoons: towards an ecosystems integration (A. Yanez-Arancibia, ed.), p. 35-56. UNAMICML Publishers, Mexico City.

Dillon, W. R., and M. Goldstein.

1984. Multivariate analysis: methods and applications, 608 p. John Wiley \& Sons, New York.

Dinnel, S. P., and W. J. Wiseman.

1986. Fresh water on the Louisiana and Texas shelf. Cont. Shelf Res. 6:765-784. Article

Douglas, A. V., and P. J. Englehart.

1981. On a statistical relationship between autumn rainfall in the central equatorial Pacific and subsequent winter precipitation in Florida. Mon. Weather Rev. 109: 2377-2382. Article

Enfield, D. B., A. M. Mestas-Nuñez, and P. J. Trimble. 2001. The Atlantic Multidecadal Oscillation and its re- lation to rainfall and river flows in the continental U.S. Geophys. Res. Lett. 28:2077-2080. Article

Fore, P. L.

1970. Oceanic distribution of eggs and larvae of the Gulf menhaden. In Report of the Bureau of Commercial Fisheries Biology Laboratory, Beaufort, N. C., for the fiscal year ending June 30, 1968. U.S. Fish Wildl. Serv. Circ. 341:11-13.

Govoni, J. J.

1993. Flux of larval fishes across frontal boundaries: examples from the Mississippi River plume front and the western Gulf Stream front in winter. Bull. Mar. Sci. 53:538-566.

1997. The association of the population recruitment of gulf menhaden, Brevoortia patronus, with Mississippi River discharge. J. Mar. Syst. 12:101-108. Article

Govoni J. J., D. E. Hoss, and D. R. Colby.

1989. The spatial distribution of larval fishes about the Mississippi River plume. Limnol. Oceanogr. 34:178-187. Article

Govoni, J. J., and C. B. Grimes.

1992. The surface accumulation of larval fishes by hydrodynamic convergence within the Mississippi River plume front. Cont. Shelf Res. 12:1265-1276. Article

Grimes, C. B., and J. H. Finucane.

1991. Spatial distribution and abundance of larval and juvenile fish, chlorophyll and macrozooplankton around the Mississippi River discharge plume, and the role of the plume in fish recruitment. Mar. Ecol. Prog. Ser. 75:109-119.

Guillory, V., J. Geaghan, and J. Russel.

1983. Influence of environmental factors of Gulf menhaden recruitment: an update. La. Dep. Wildl. Fish. Tech. Bull. 37, 32 p.

Guillory, V., and J. Roussel.

1981. Seasonal and areal abundance of Gulf menhaden in Louisiana estuaries. Proc. Annu. Conf. Southeast. Assoc. Fish Wildl. Agencies 35:365-371.

Gunter, G.

1945. Studies on marine fishes of Texas. Publ. Inst. Mar. Sci., Univ. Tex. 1:1-190.

Henderson K. G., and A. J. Vega.

1996. Regional precipitation variability in the southern United States. Phys. Geogr. 17:93-112.

Hettler, W. F., Jr.

1984. Description of eggs, larvae, and early juveniles of gulf menhaden, Brevoortia patronus, and comparisons with Atlantic menhaden, B. tyrannus, and yellowfin menhaden, B. smithi. Fish. Bull. 82:85-95.

Hitchcock, G. L., W. J. Wiseman Jr., W. C. Boicourt, A. J. Mariano, N. Walker, T. A. Nelsen, and E. Ryan.

1997. Property fields in an effluent plume of the Mississippi River. J. Mar. Syst. 12:109-126. Article

Hurrell, J. W., and H. Van Loon.

1997. Decadal variations in climate associated with the North Atlantic Oscillation. Clim. Change 36:301-326. Article

Kirby, C. J.

1972. The annual net primary production and decomposition of the salt marsh grass Spartina alterniflora Loisel in the Barataria Bay estuary of Louisiana. Ph. D. diss., 81 p. Louisiana State Univ., Baton Rouge, LA.

Lohrenz, S. E., M. J. Dagg, and T. E. Whitledge.

1990. Enhanced primary production at the plume/oce- 
anic interface of the Mississippi River. Cont. Shelf Res. 10:639-664. Article

Madden, C. J., J. W. Day Jr., and J. M. Randall.

1988. Freshwater and marine coupling in estuaries of the Mississippi River deltaic plain. Limnol. Oceanogr. 33:982-1004.

Moeller, C. C., O. K. Huh, H. H. Roberts, L. E. Gumley, and W. P. Menzel.

1993. Response of Louisiana coastal environments to a cold front passage. J. Coast. Res. 9:434-447.

Ram, N. M., and S. Plotkin.

1983. Assessing aquatic productivity in the Housatonic River using the algal assay bottle test. Water Res. 17:1095-1106. Article

Redfield, A. C.

1958. The biological control of chemical factors in the environment. Am. Sci. 46:205-222. [Available at website.]

Reintjes, J. W.

1970. The Gulf menhaden and our changing estuaries. Proc. Gulf Caribb. Fish. Inst. 22:87-90.

Renfro, W. C.

1963. Small beam net for sampling postlarval shrimp. In Biological Laboratory, Galveston, Tex., fishery research for the year ending June 30, 1962, p. 86-87. U.S. Fish Wildl. Serv. Circ. 161. [Available at website.]

Riley, G. A.

1937. The significance of the Mississippi River drainage for biological conditions in the northern Gulf of Mexico. J. Mar. Res. 1:60-74.

Rogers, J. C., and J. S. M. Coleman.

2003. Interactions between the Atlantic Multidecadal Oscillation, El Niño/La Niña, and the PNA in winter Mississippi Valley stream flow. Geophys. Res. Lett. 30:1518. Article

Sakshaug, E., and Y. Olsen.

1986. Nutrient status of phytoplankton blooms in Norwegian waters and algal strategies for nutrient competition. Can. J. Fish. Aquat. Sci. 43:389-396. Article

Sanchez-Rubio, G., H. M. Perry, P. M. Biesiot, D. R. Johnson, and R. N. Lipcius.

2011a. Oceanic-atmospheric modes of variability and their influence on riverine input to coastal Louisiana and Mississippi. J. Hydrol. 396:72-81. Article

2011b. Climate-related hydrological regimes and their effects on abundance of blue crabs (Callinectes sapidus) in the northcentral Gulf of Mexico. Fish. Bull. 109:139-146.

Shaw, R. F., B. D. Rogers, J. H. Cowan Jr., and W. H. Herke.

1988. Ocean-estuary coupling of ichthyoplankton and nekton in the northern Gulf of Mexico. Am. Fish. Soc. Symp. 3:77-89.

Shaw, R. F., W. J. Wiseman Jr., R. E. Turner, L. J. Rouse Jr., R. E. Condrey, and F. J. Kelley.

1985. Transport of larval gulf menhaden Brevoortia patronus in continental shelf waters of western Louisiana: a hypothesis. Trans. Am. Fish. Soc. 114:452-460. Article
Smith, J. W.

1991. The Atlantic and gulf menhaden purse fisheries: origins, harvesting technologies, biostatistical monitoring, recent trends in fisheries statistics, and forecasting. Mar. Fish. Rev. 53:28-39.

Smith, S. D.

1980. Wind stress and heat flux over the ocean in gale force winds. J. Phys. Oceanogr. 10:709-726. Article

Smith, S. V.

1984. Phosphorus versus nitrogen limitation in the marine environment. Limnol. Oceanogr. 29:1149-1160. Article

Sogard, S. M., D. E. Hoss, and J. J. Govoni.

1987. Density and depth distribution of larval gulf menhaden, Brevoortia patronus, Atlantic croaker, Micropogonias undulatus, and spot, Leiostomus xanthurus, in the northern Gulf of Mexico. Fish. Bull. 85:601-609.

Suttkus, R. D.

1956. Early life history of the Gulf menhaden, Brevoortia patronus, in Louisiana. Trans. N. Am. Wildl. Conf. 21:390-407.

Tootle, G. A., and T. C. Piechota.

2006. Relationships between Pacific and Atlantic ocean sea surface temperatures and U.S. streamflow variability. Water Resour. Res. 42, W07411. Article

Tolan, J. M., and D. A. Newstead.

2004. Descriptions of larval, prejuvenile, and juvenile finescale menhaden (Brevoortia gunteri) (family Clupeidae) and comparisons to gulf menhaden (B. patronus). Fish Bull. 102:723-732.

Tootle, G. A., T. C. Piechota, and A. Singh.

2005. Coupled oceanic-atmospheric variability and U.S. streamflow. Water Resour. Res. 41, W12408. Article

Vaughan, D. S., J. J. Govoni, and K. W. Shertzer.

2011. Relationship between Gulf menhaden recruitment and Mississippi River flow: model development and potential application for management. Mar. Coast. Fish 3:344-352. Article

Vaughan, D. S., K. W. Shertzer, and J. W. Smith.

2007. Gulf menhaden (Brevoortia patronus) in the U.S. Gulf of Mexico: fishery characteristics and biological reference points for management. Fish. Res. 83:263-275. Article

Vaughan, D. S., J. W. Smith, and M. H. Prager.

2000. Population characteristics of Gulf menhaden, Brevoortia patronus. NOAA Tech. Rep. NMFS 149. 19 p.

Wiseman, W. J. Jr., and R. W. Garvine.

1995. Plumes and coastal currents near large river mouths. Estuaries 18:509-517. Article

Wiseman, W. J. Jr., and F. J. Kelly.

1994. Salinity variability within the Louisiana coastal current during the 1982 flood season. Estuaries 17: 732-739. Article

Wright L. D., and J. M. Coleman.

1971. Effluent expansion and interfacial mixing in the presence of a salt wedge, Mississippi River delta. J. Geophys. Res. 76:8649-8661. Article 